\title{
水田における蚊幼虫の発生動態に関する研究 とくに稲作管理との関係をめぐつて

\author{
Studies on the population dynamics of mosquito \\ larvae in a paddy field, with the special reference \\ of the relation between rice plant farming and \\ breeding of mosquito larva
}

\author{
緒方一喜2) 中 山 孝夫3) \\ Kazuki Ogata and Takao Nakayama
}

わが国の農村地帯に広く拡がる水田は，大量のコガタ アカイエカ, シナ八マダラカを発生させ，農村地域にお ける最も重要な蚊の発生源である。すなわち，水域が広 大であることから発生量ははなはだ大であり，また，発 生種は，それぞれ日本脳炎，マラリヤの媒介種として重 要である上に，人畜に対して強い吸血性を持ち，農村に おける蚊の問題は，水田に集約されるといつても過言で ない。

一方，このような重要性にも拘わらず，水田に対する 蚊対策注現実には全く行なわれていない：これは，水域 が余りに広大なために，処理し難いといらこと，農家の 生産の場であるために，容易に手をつけ難いことなどが 主な理由であろう，著者らは，水田性の蚊の防除法を確 立する目的で 1961 年来, 調查および実験を行なつてい る. 第 1 報として，1962 年度に水田における発生実態を 特に稲作管理との関倸において観察したのでその結果を 報告する。

なお，本調查においては，予研衛生昆虫部長朝比奈正 二郎博士，川崎市高津保健所稻田支所長水谷久泰博士に 種々御指導を頂いた。 また，調查水田の所有主石川甚藏 氏には，種々御協力を頂いた。この機会に厚く御礼を申 し上げる。

\section{調查方法}

\section{1. 場 所}

1）水田の蚊に関する研究 第 1 報

2）国立予防衛生研究所衛生昆虫部 Department of Medical Entomology, National Institute of Health, Tokyo

3）川崎市高津保健所

Takatsu Public Health Center, Kawasaki City
川崎市生田の 石川甚蔵氏所有の 約 42 アールの水田を 使用した. 水田のすぐ南側は, 小田急の線路をはさんで 丘陵が続き, 北側もまた，県道をはさんで民家数戸を隔 てて丘陵がある. 東西方向にはややひらけている地形で ある。

水田は南側がやや高く，階段状をなして，北側に低く なっている. 南側の中央付近に用水路が開口し, 灌溉水 は水田の中を通つて北側に流九落ちる.

図 1 亿示すよ $5 に ， 24$ 筆の水田中, 蚊幼虫, サナギの 発生数を観察記録したのは 10 筆で，P 2 P 6 は，後述 するよ5にヒシャクで定量採集を行なつた水田で，S2 Ｓ11 は，出現率を見た水田である、補助的に，用水路 P1・S1での観察をも行なつた.

また，図示したように，水田に接した西北側にライト トラップを設置して成虫の捕集を行なつた.

\section{2. 期 間}

1962 年 3 月 28 日から 11 月 8 日までの間 35 回の観察 を行なつた。原則として週 1 回の間隔で観察を行なつた が，必要により回数をましたこともあつた。

\section{3. 钼察の方法}

(1) 幼虫, サナギの発生数の定量観察法

水田 5 枚, 用水路 1 本において発生数の定量観察を行 なつた．図1にお゙いて，P1～P 6 で示す水域である.す なわち，1枚の水田で幼虫, サナギの多、場所から， 匕 シャクで 5 回の寸くいとりを行なつた．ヒシャクは，直 径約 $13 \mathrm{~cm}$, 梁さ約 $6.5 \mathrm{~cm}$ の市販の普通のものである. 捕集された虫は研究室に持ち帰り，鏡検して同定した. サナギは原則として成虫まで羽化させて同定した.

（2）幼虫，サナギの発生指数のとり方

視察および，ヒシャクによる適宜なすくいとりにより 


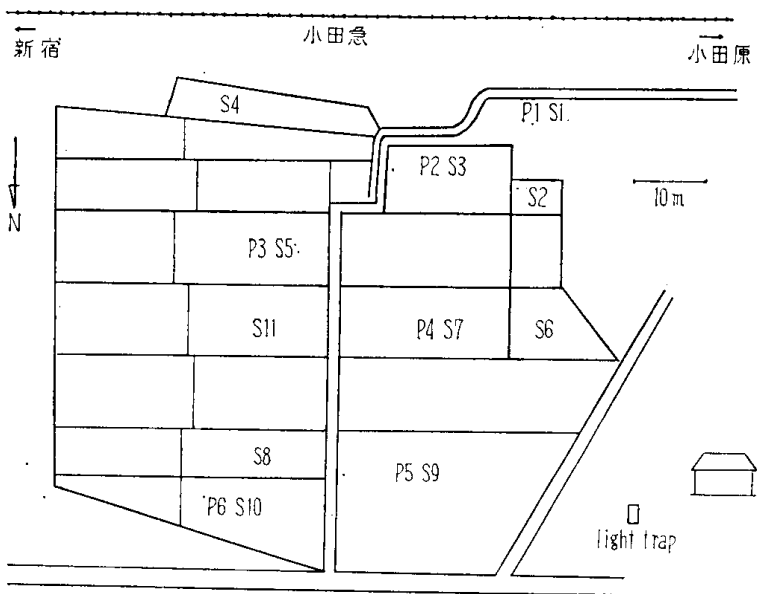

図 1 調查水时概略図川崎市生田

その水田におけるおよその発生数を推定し，これを発生 指数として記録した． 10 枚の水田，1 本の用水路におい てこれを行ない，蚊の種類は属の単位でまとめた，発生 指数には次の 5 段階を設けた。 すなわち, 推定発生数が 0 の場合は (一), $1 \sim 9$ 匹の場合 $(+), 10 \sim 99$ 匹の場合 (\#)，100 999 匹の場合（\#)，1,000匹以上の場合を (冊) とした.

（3）成虫の捕集方法

観察水田のすぐ横に，伝研型ライトトラップ 1 基を設 置して, 成虫の捕集を行なつた. $60 \mathrm{~W}$ 白色電球を光源 とし, 地上高約 $5 \mathrm{~m}$ の樹上に吊り下げた. 原則として週 1 回, 幼虫調查の日の夜に行ない，日没より日出までの 終夜運転を行なつた。

\section{（4）環境条件の测定}

蚊の発生と環境条件の間の関倸を探る目的で次の各種 条件の測定を行なつた。

温度 : 気温測定には, 最高最低水銀温度計を，水温测 定には，棒状アルコール温度計を使用した。 P $1 \sim \mathrm{P} 6$ において調查每に水温を測つた。な扔，日平均気温の資
料は, 神奈川県気象月報から, 西生田小学校における観 測資料を利用した。

透視度：P1 P 6 において，調査毎に水田の水を採 水し，その澄明の度を記録した。指度は，5号活字を判 読できる最少の水層の高さ $(\mathrm{cm})$ をもつて示した，既製 の透視度計を使用した。

$\mathrm{pH}$ 值: $\mathrm{P} 1 \sim \mathrm{P} 6$ 亿抒いて採水して $\mathrm{pH}$ 值の測定を行 なつた. 比色法によつた。

$\mathrm{COD}$ : 水の污染度を知る目的で, 過マンガン酸カリ法 による COD の測定を行なつた．P1〜P6において調 查時に採水し，研究室に持ち帰つて処理した。

湛水状況: 調査回毎に, 湛水面積を, 満水時を 100 上 した指数で記録した．また，水深を一筆毎に数力所測定 して，その平均值を記録した。

\section{成績および考察}

\section{1. 捕集された蚊の種類とその構成}

1962 年 3 月から 11 月までの 1 シーズン中に捕集され た蚊の種類と数を表 1 に示した. 幼虫は 3 属 8 種，サナ ギは 3 属 5 種，成虫は 4 属 6 種捕集された.

幼虫で多かつたものは，シナハマダラカ Anopheles sinensis(以下 $\sin$ と略称) と，コガタアカイエカ Culex tritaeniorhynchus (trit) で，それぞれ 49.4\%，41.7\% を占め，圧倒的であつた。 これについで，コガタクロウ スカ Culex hayashii (hay), キンイロヤブカ Aedes vexans (vex), カラツイエカ Culex bitaeniorhynchus (bit) がとれたが，前 2 種に比心゙れば数は著るしく少な かつた.

ところが，サナギの捕集種構成を見ると，幼虫とはを の様相をはなはだ異にしている。すなおち， tritが 58.4 $\%$ と過半数を占め, ついで vex が多く, sin 3 位で あつた，その理由については審らかでないが，想像され る2つのこととして，サムプリング法の不備と，種によ

表 1 水四調查に㧍いて一年間に捕集された蚊の種類 1962 年 4 月 月 11月

\begin{tabular}{|c|c|c|c|c|c|c|}
\hline & 㭃 & 虫 & サ & ナ ギ & 成 & 虫 \\
\hline Anopheles sinensis & 1,219 & $49.4 \%$ & 21 & $13.5^{\%}$ & 592 & $27.6 \%$ \\
\hline Culex tritaeniorhynchus & 1,028 & 41.7 & 91 & 58.4 & 1,148 & 53.6 \\
\hline Culex hayashii & 101 & 4.1 & 2 & 1.3 & 0 & \\
\hline Aedes vexans & 67 & 2.7 & 32 & 20.5 & 330 & 15.8 \\
\hline Culex bitaeniorhynchus & 25 & 1.0 & 10 & 6.3 & 0 & \\
\hline Culex orientalis & 10 & 0.4 & 0 & & 0 & \\
\hline Anopheles sineroides & 9 & 0.4 & 0 & & 5 & 0.2 \\
\hline Culex pipiens & 7 & 0.3 & 0 & & 62 & 2.7 \\
\hline Armigeres subalbatus & 0 & & 0 & & 1 & 0.1 \\
\hline total & 2,466 & & 156 & & 2,138 & \\
\hline
\end{tabular}




\section{る発育過程中の死亡率の違いがある.}

サムプリングの方法としては, 前述したように，1枚 の水田で多い䈯所から 5 回，ヒシャクで採水して，捕集 幼虫数を算定した. 具体的には，5回以上採水して算定 し，多い方からの5回分の虫数を合計したのである。一 方, 水中に打ける幼虫, サナギの行動分布を見ると, $\sin$ は，アオミドロなどの緑藻中に多く集まる傾向があ り, 分布密度ははなはだしく不均一である. そして水面 に静止することが多い，これに対して，tritは，浮遊物 のない水中を遊泳し，またそんな水面に静止し， sin ほ どの集中性がみられない. vexは，tritよりもさらに分 布が均一なよらで，しかも，水底に下りる機会が trit よりも多いようである。このような種の間の行動習性の 違いが，水面をヒシャクですくらというサムプリングの 結果に表われて，幼虫では， sin が過大にとれ，vexは 過少にとれたのではないかと推察される.かといつて， サナギに扔ける構成比がそのまま実態に近いかどうか は，さらに検討の余地があろう。調查を通じて得た印象 では，幼虫とサナギの構成比の中間に実態があるように 感じた，成虫の捕集構成比がそれに近いのではないだろ らか. もつとも， ライトトラップの誘引範囲は, 調査 水田以外の種々の水域, 地域を含むので, アカイエカ Culex pipiens やオオクロヤブカ Armigeres subalbatus は，水田以外のものが多く入つていることが想像され る.また, bit やhay は, 他種に比して, 灯火誘引性 が低いのではないかということも想像される。

ともあれ，この地方での水田における主要発生種は， trit, sin, vex の 3 種で, とりわけ前 2 種が多いという ことがいえる.そして，3種とも，人畜に対して激しい 吸血性をもち，没学的にも重要であることは，農村にお ける蚊の発生源としての水田の重要性を示すものであ る.

\section{2. 水域別の蚊の分布}

1 本の用水路 (P 1) と 5 枚の水田 (P 2 P 6 ) について は，周年的に定量調查を行なつた。そこで，これら6力 所の水域別に，発生種の違いがあるかどうかを検討して みた. 図 2 は, 各水域毎に, 蚊の百分率種構成を示した ものである. 䋛軸に捕集数の百分率をとり，座標上に百 分率の信頼幅 (信頼度 $90 \%$ の Neyman 流)を棒で示し， 標本值を実線で結んだ.

6 水域は，2 型に分けることができる．1つ注用水路 のP1で，ここでは，hayが優占種であつた.すなわち 約 $57 \%$ 占め，trit， sin は，それぞれ約 $20 \%$ 占める にすぎなかつた．この用水路は南側の丘陵の間をぬつて くる小川から引つぱつたもので, 幅は約 $30 \mathrm{~cm}$, 従来は 清澄な水であつたそうである。近年汢付近の宅地造成で

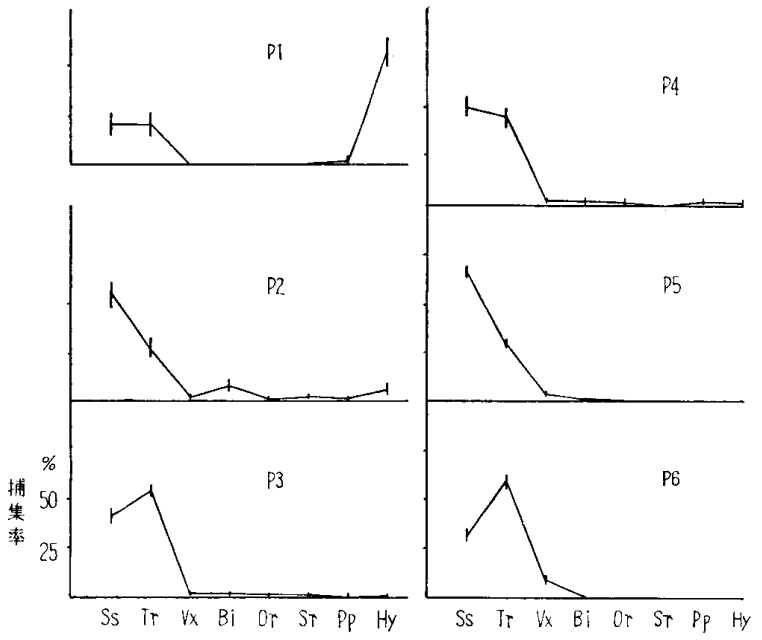

Ss A. sinensis, $\operatorname{Tr} C$. tritaeniorhynchus, $\mathrm{Vx}$ $A$. vexans, $\mathrm{Bi} C$. bitaeniorhynchus, Or $C$. orientalis, $\mathrm{Sr} A$. sineroides, $\mathrm{Pp} C$. pipiens, Hy C. hayashii

図 2 各水域に打沙蚊の百分率種構成

かなり民家の污水が入つてくるようであるが，図 4 にみ られるように, COD 8.6, pH 6.99, 透視度 29.2 (それ ぞれ年間平均) が示すよらに，肉眼的にはまだきれいな 水である．灌水している時には，中央付近はよく流れる が，岸の雑草付近にはよどみができる。

他の型は，P 2 P 6 の水田にみられる型で, $\sin$ 上 trit が優占的な型である. P 2, P 5 では sin，P $3 ，$ P6 では trit が有意差をもつて多いが断定はしにくい.上 いうのは図 4 の水域別環境要因の比較をみても $\mathrm{P} 2, \mathrm{P}$ 5 と P 3, P6 とはそれほど違つた条件の水域とは思え
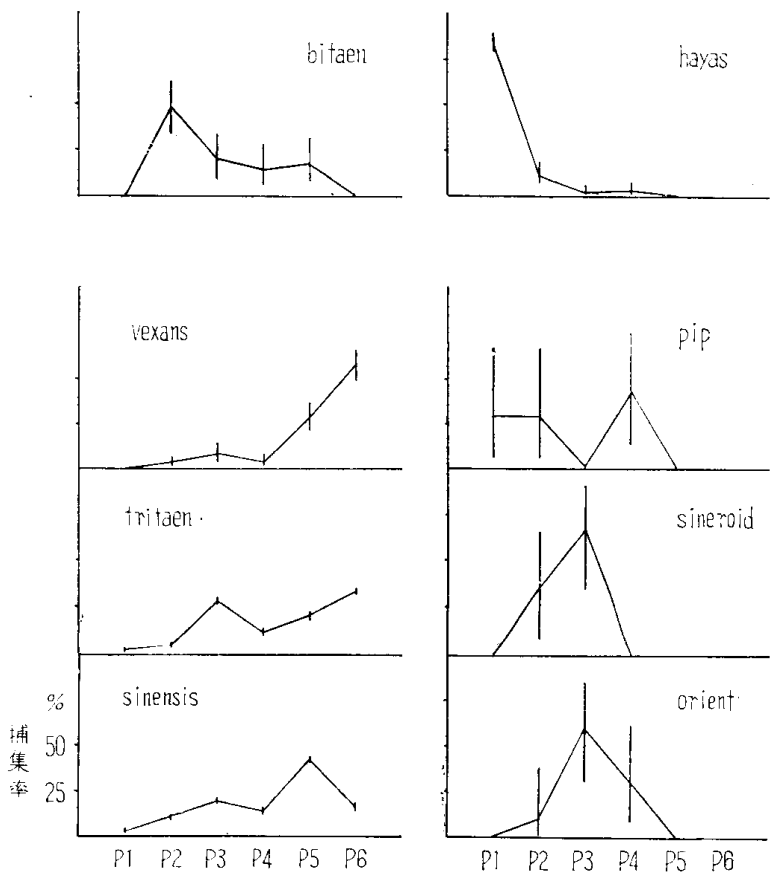

园 3 各種蚊の水域別百分率構成 
ない. 以上のことから, 用水路においては, hay が優占 的であり，水田に扔いては sin, trit が優占的であると 考えてよいだろう。

次に, 蚊の種類別に, 各水域間の分布をみてみると, 図 3 のようになる。．その分布加ら，蚊は 4 型に分けるこ とができそうである.1つは, sin, trit, vexの 3 種が 示寸型で用水路に注少く水田では $\mathrm{P}$ 番号がふえるほど多 い.P 3 がやや多いが，ここ注苗代を作る田で，湛水期 問が他より長いためである。つまり，北側の田ほど, 下段の田ほど多いといらことである。この 3 種は，他の 種類に比べて捕集数が著るしく多いので，北側の田ほど 蚊の生産量が多いといらことを示している.この理由に ついて，図4亿示した環境条件との関連で吟味してみる

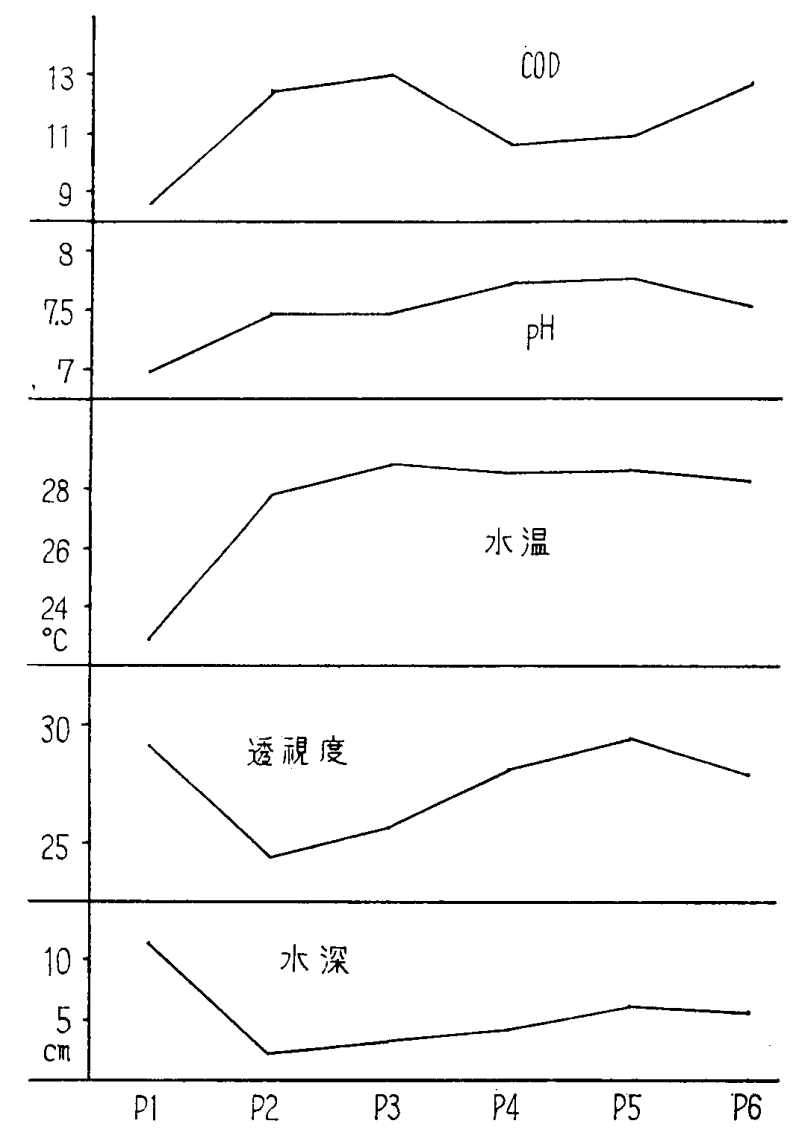

図 4 各水域別の環境要因

6 月 14 日 9月 5 日間 13 回分の測定值の平均

と, 水温, COD は各水域の間で違いはみられないが, 北側ほど $\mathrm{pH}$ 值はアルカリ性で, 透視度は大きく, 水深 も墚い．この間にどのような因果関倸があるのか速断は できないので，ここで注資料を提出するに止めたい．

第 2 の型は bit である. vex 型と逆に, 用水路にはい ないが，水田では南側ほど多い傾向がある.

第 3 の型は hay で, 前述したように水田には少く, 用水路に圧倒的に多い. pip, エセシナ八マダラカAnopheles sineroides (sineroid), ハマダラウスカ Culex orientalis の 3 種は捕集数が少く論議の対象にならな ᄂ.

\section{3. 各種の蚊の季節的出現消長}

各種の蚊の出現消長を 図 5 に示した. P $1 \sim \mathrm{P} 6$ で定 量採集された幼虫とサナギの合計数を実線で，ライト卜 ラップでとれた成虫を点線で示した.

trit の幼虫注 6 月 21 日に初めて捕えられ，まもなく 急激な增加を示し，7月11日にピークを示した，その 直後急隇するがこれはパラチオン散布のためである。こ の減少む数日でまむなく回復するが，7月下旬から始ま る中干しによつて再び減少し，ここに第2のピークを作 る.度重なる中干しによつて発生を抑えられていた幼虫 も, 8 月下旬から 9 月上旬にかけての穂ばらみ期の長期 灌水でまたピークを作る. そして 9 月 13 日の落水で水 田から姿を消した. 寸なわち, 幼虫は, 7 月 11 日前後, 7 月 23 日前後, 8 月 28 日〜 9 月 5 日, の 3 回のピーク を示した。 これに対して，成虫は長期間にわたつて捕集 されたが，7月 20 23 日に急激な1つのピークを作つ たに過ぎなかつた。 6 月 8 日に初めてとれ，11月 2 日が 最後であつた. 盛期は 6 月 14 日から 9 月 5 日までの間 であつた。

$\sin$ の幼虫は trit より早く 5 月 25 日初めて出現した. その後 7 月 5 日からふえ始めたが, 7 月 14 日のパラチオ ン散布で一度減り, 再びふえたが， 7 月下旬の中干しで また減少した。しかし 8 月上旬， 9 月上旬にもピークが あつたすなおち，小さいピークが 4 回みられた．大き くみれば 8 月 9 日のピークを最高に前後に低い.しかし この日の捕集幼虫は寸べて瞬化直後の幼虫であつた．た またま蜉化卵塊付近をすくつたためによるものらしい， したがつて，このような配慮で消長をみると，7月上旬， 7 月下旬, 9 月上旬の 3 ピークがあつたと解釈した方が よい：これに対し成虫は，6月 1 日から9月20日までと れたが, 多いのは 7 月20日から 8 月 9 日までであつた.

vex は， 5 月上旬， 6 月中旬， 8 月中旬に少数ずつ現 われた．中でも 6 月中旬に多かつた。 すなわち， sin， trit の多い 7 月には姿を消し，その前後に出現した。成 虫は 6 月上, 中旬に多かつた. hay 幼虫は，6月下旬， 8 月下旬, 9 月上旬に多く現われ，盛夏には少なかつ た. bit 幼虫は 7 月上, 中旬にほんの短期間にとれたに すぎなかつた。

\section{4. 蚊幼虫の発生と稲作管理の閶係}

すでに前項で一部述べたように, 水田における蚊幼虫 の発生は, 稲作管理と密接な関係をもつている.ここで は, 稻作の作業歴を追つて, 蚊幼虫の発生との関係を追 求してみる. 図 6 にその成績を図示した. 最上段に幼虫 (実線) と成虫 (点線)の出現消長を示した. 捕集された全 

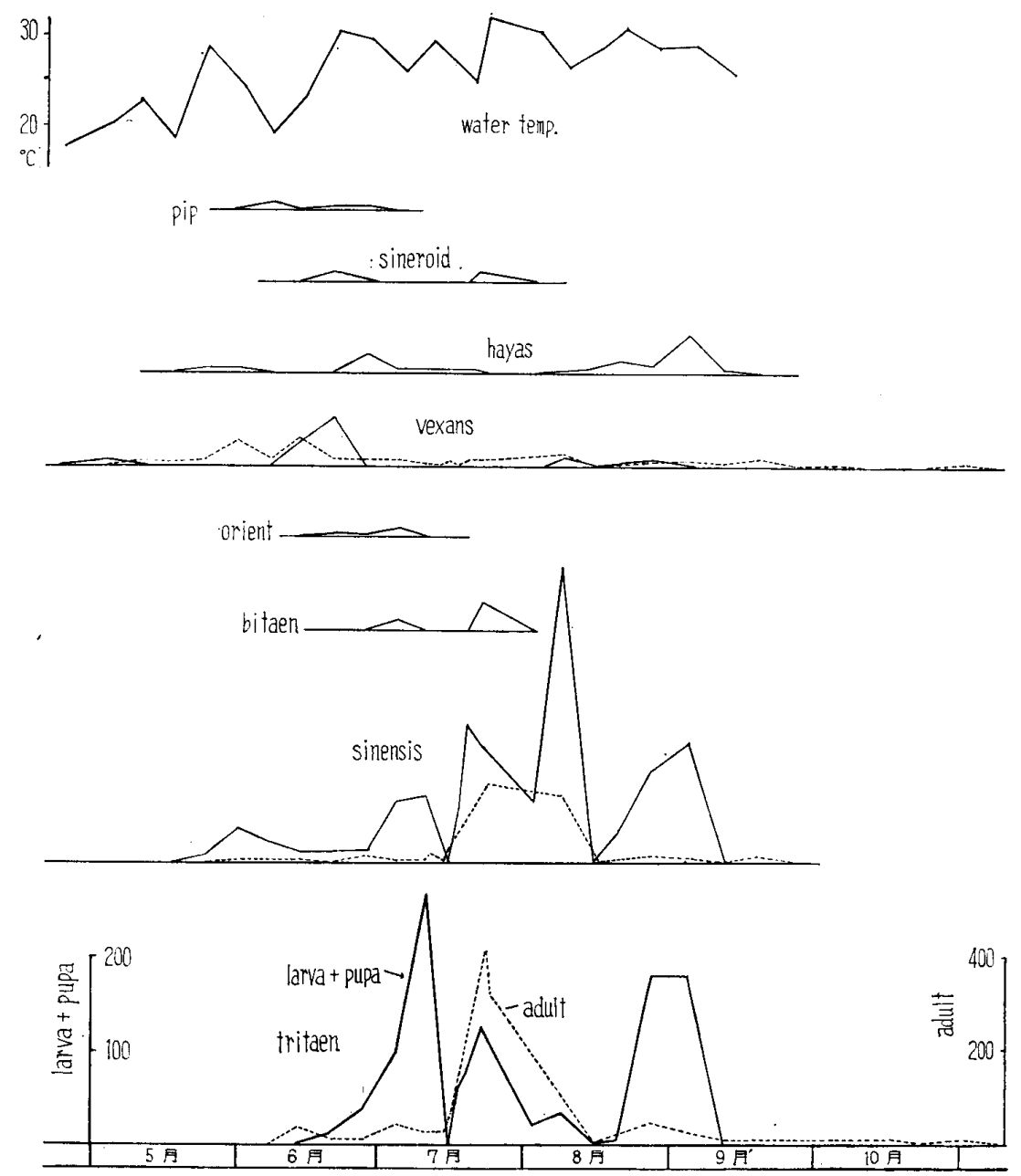

図 5 水田に打ける蚊の年間発生消長 川崎・生田 1962年

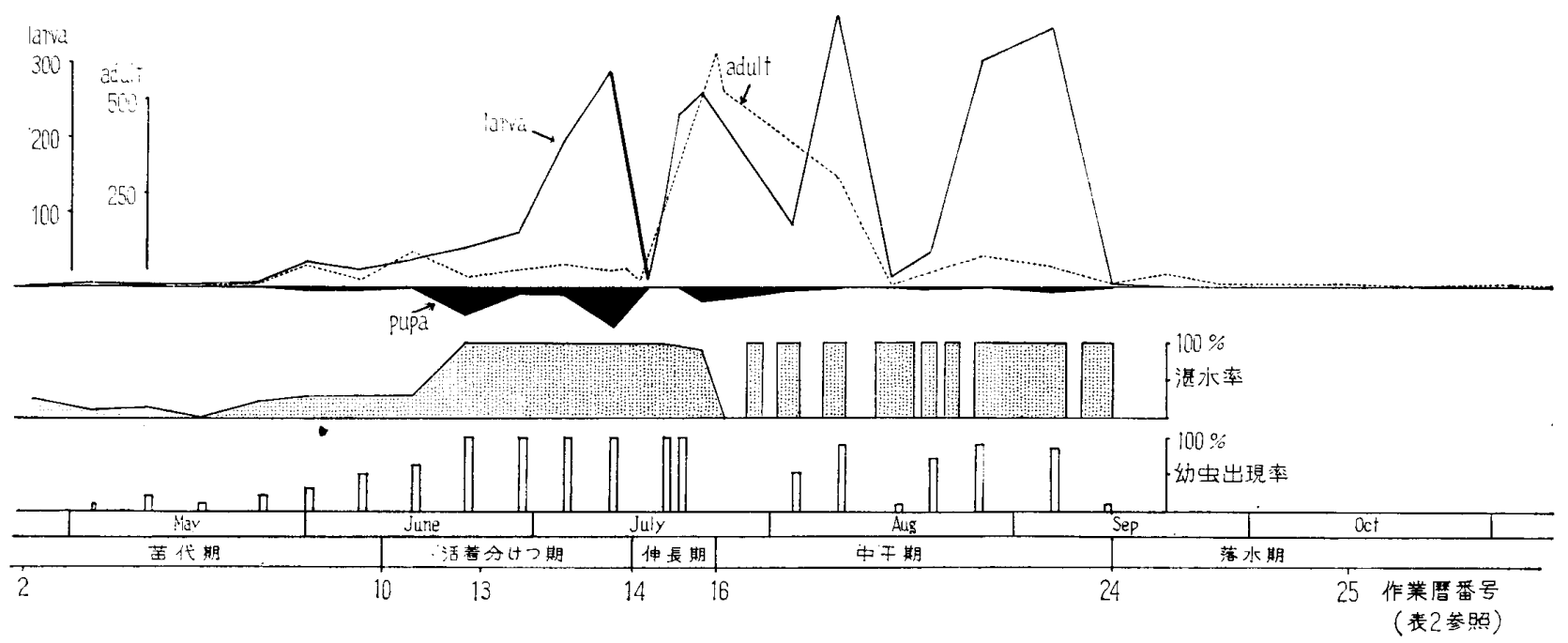

図 6 水田における蚊の発生と稲作 川䐀・生田 1962年

種類の総数をまとめてだした．黒くつぶした波は同様に サナギの出現消長である．中段の点でつぶしたものは湛 水率の消長を示している.すなわち, 調査水田総面積に 占める湛水田の百分率をむつて表わしている，その下の 棒グラフは幼虫出現率で, 調查水田 10 枚中に占める蚊
幼虫発生水田の百分率をもつて表わしている．月の欄の 下の最下段に表 2 作業歴番号でその時の作業を示し t.

調査水田の裏作は一部分の田で行なわれていた。すな わち, 北側 10 枚の田で, 裸麦, 苸, えんどう, なたね, 
表 2 調查水四の稲作作業暦 1962年

\begin{tabular}{|c|c|c|c|c|c|}
\hline 番号 & 月 & 日 & 作 & 業 & 備 \\
\hline 1 & \multirow[t]{4}{*}{4} & 13 & 耕 & 起 & 苗代の準備 \\
\hline 2 & & 22 & 灌 & 水 & 苗代のみ，代搔き \\
\hline 3 & & 22 & 耕 & 起 & 本时の準備開始 \\
\hline 4 & & 25 & 施 & 肥 & 苗代に配合肥料 $26.2 \mathrm{~kg}$, し布散布 \\
\hline 5 & \multirow[t]{2}{*}{5} & 1 & 播 & 種 & 苗代 \\
\hline 6 & & 4 & 施 & 肥 & 苗代に焼灰散布 \\
\hline 7 & \multirow[t]{7}{*}{6} & 7 & ク & x 1 & 南側本时 \\
\hline 8 & & 9 & 耕起・ク & ロヌリ & 北側本目 \\
\hline 9 & & 10 & 施 & 肥 & 配合肥料 $80 \mathrm{~kg}$ ，鶏䔬 7 俵，し尿 18 荷. 南側本田に \\
\hline 10 & & 11 & 回 & 植 & 南側本田 \\
\hline 11 & & 16 & 施 & 肥 & 配合肥料 $240 \mathrm{~kg}$, 彩程 7 俵. 北側本时に \\
\hline 12 & & 17 & 时 & 植 & 北側本田 \\
\hline 13 & & 24 & 除 & 草 & PCP $25 \%$ 粒削 $12 \mathrm{~kg}$ 散布 \\
\hline 14 & \multirow[t]{4}{*}{7} & 14 & 殺虫 & 剂 & Methyl parathion $40 \%$ 乳剂 1,500 㥉液 $75 \mathrm{l} / 10 \mathrm{a}$ 散布 \\
\hline 15 & & 20 & 除 & 草 & 人力 \\
\hline 16 & & $25 \sim 28$ & 中 干 & (1) & \\
\hline 17 & & $30 \sim 2$ & 中 干 & $(2)$ & 配合肥料組成 \\
\hline 18 & \multirow[t]{5}{*}{8} & $5 \sim 8$ & 中干 & $(3)$ & 硫 安 $32.5 \%$ \\
\hline 19 & & $11 \sim 15$ & 中 $\mp($ & (4) & 過 燐 $50.0 \%$ \\
\hline 20 & & 20 & 中 $干$ & $5)$ & 壏 加 $17.5 \%$ \\
\hline 21 & & $22 \sim 23$ & 中 于 ( & (6) & \\
\hline 22 & & $25 \sim 26$ & 中 干（ & $(7)$ & \\
\hline 23 & \multirow[t]{2}{*}{9} & $8 \sim 9$ & 中 干（ & $8)$ & \\
\hline 24 & & 13 & 落 & 水 & \\
\hline 25 & \multirow[t]{3}{*}{10} & 13 & 稲 & XII & 北側一部 \\
\hline 26 & & 17 & 稲 & $X \mid]$ & 北側残り \\
\hline 27 & & $24 \sim 25$ & 稲 & 杊 & 南側 \\
\hline
\end{tabular}

レンゲなどが栽培され，南側 14 枚は休䦥田として放置 されていた。

なお，作業歴は，蚊幼虫の発生との関連で便宜的に次 の 4 期に区分できた.

第 1 期(苗代期)：苗代作りから田植まで. 4月13日〜 6 月 10 日.

第 2 期 (活着分けつ期) : 田植からパラチオン散布まで. 6 月 11 日 2 月 13 日.

第 3 期 (伸長期):パラチオン散布から中干し開始まで. 7 月 14 日 7 月 24 日.

第 4 期(中干期)：中于し開始から落水まで. 7 月 25 日 $\sim 9$ 月 12 日.

各期を抽つて，蚊の発生と作業との関係を追求してみ たい.

(1) 第 1 期 (苗代期)

この年の稲作作業は，まず4月13日の，苗代田（P 3 ）の耕起から始まつた。 ついで 22 日から灌水が始ま
り，代搔きが行なわれた。苗代作りと闰時に配合肥料 $26.2 \mathrm{~kg}$ と人糞尿が苗代に施用された。また，P 2, P 3 でも耕起が始まつた。この頃は，P３湛水し，それ以 外の休閑田でも地表面に水たまりがあつたり，また，耕 起した士塊の間にも多くの水たまりがあるが，まだ幼虫 の姿はみられない。

最初の幼虫発見は 5 月 4 日で, 耕起した土塊の間の水 たまりに，vex幼虫が数多くみられた。ついで 5 月 11 日 には，やはり土塊の間に，多くのrex，お上び少数の sineroid が散見された。苗代にはじめて幼虫が出現した のは 5 月 25 日で, sin, hay が見受けら机た。しかし発 生数はまだ多くない， sin が多くなるのは6月1日加 である。だが，まだ湛水面積が狭いので，発生総数はそ れほどでもない。

第 1 期の特長としては，まだ湛水面積が惓く，また， 季節的にも時期が早いために，幼虫の発生量は少ない. しかし，6月 2 日には，ライトトラップに 1 晚で 57 匹の 
vex がとれ，また，付近の住民は，この前後に，初めて 蚊に刺されたことを述べているので，実態を過少評価し てはいけないようである。この時期には苗代および耕作 田の土塊の間の水たまりに，多くのvex れる.そして，ライトトラップの捕集蚊の $90 \%$ 以上は vex であるので，この時期の対策の要点は，vex 幼虫と いらことになろう。また， $\sin$ を発生初期に吒くという 考えがあれば， $\sin に$ 対しても重要な時期である。

(2) 第 2 期（活着分けつ期）

6 月 7 日までには麦㺫その他裏作の収獲が終り，耕作 が始まつた。 そして，6月11日と 17 日の 2 回にわたつ て田植が行なわれ，この頃から，水田は全面湛水にな る.そして, 田植直前に, 配合肥料 $320 \mathrm{~kg}$, 鶏糞 14 俵, 人糞尿 18 荷が施用された。代搔き後，田植作業や施肥 によつて，蚊の発生密度が抑えられた気配はみられなか つた.

この頃から発生幼虫数はしだいに増加する. trit が初 めてとれたのは 6 月 21 日であつた。 6 月下旬から 7 月 上旬にかけ trit の増加は著しい.この間， 6 月 24 日に 除草剤として PCP 粒剂が散布された， $25 \%$ 製剂の 12 $\mathrm{kg}$ を全面に散布したが，その濃度は概算して水量の約 $12 \mathrm{ppm}$ に当る.印象としてはすこし減つたようであつ たが，定量採集の成績からは増加を抑えるにいたつてい ない。この急激な上昇も，7月 14 日のパラチオン散布に よつて全滅した。

第 2 期の特長は, 後半にいたつて trit, $\sin$ の著るし い増加がみられる点である。特に，trit の増加が著るし い. 第 1 のピークである. vex は前半に仅られたが，後 半には姿を消した。 6 月 21 日以降においては，調査全水 域が湛水し，そして幼虫の出現がみられるようになつ た.

（3）第 3 期（伸長期）

パラチオン散布で全隇した幼虫も，4 日目には新生幼
虫が出現し，9日目にはサナギが出現し，ほぼ元の勢力 に回復した．その後依然増加の気配を示したが，7月 25 日の中干しによつて再び全滅した。この間，7月20日に 手による人力除草作業が行なわれたが，この作業でも発 生密度は落ちなかつた。

第 3 期は，パラチオンの潰滅的打撃を受けた後，再び 急激に増加する時期である. sin, trit とも回復は著るし W.

(4) 第 4 期（中干期）

7 月 25 日の第 1 回の中干し以来， 9 月 13 日の落水ま で, 8 回の中干しが断続して行なわれた. その中干し期 間と灌水期間の交替の模様を示すと次の通りである.

中干し-(灌水) -4 日一- $(1$ 日) -4 日一-(2 日) -4 日 $-(2$ 日) -5 日一 $-(4$ 日) -1 日- $(1$ 日) -2 日 $-(1$ 日) -2 日一-(13日) -2 日一-( 4 日) 一落水

これからも分るように，非常に小刻みな中干しと灌水 の繰返しが行なわれた．調査水田は，もともと排水の悪 い田であつたのが，約 20 年前に土地改良を行ない，地 下に孟宗竹を埋め込んで，水はけがよいように改良され ている：そのため, 用水路からの水口をふさぐと 1,2 日 でほぼ完全に干田化する，だから，このような小刻みな 灌水の調節に対して, 水田中の水位は敏感に動き, 容易; に干田化する。

図 6 に示されるように，中干期の間の幼虫数のポピュ レーションは大きく変動する。すなわち，干田化すると 幼虫はほぼ全滅する。しかし灌水されると直ちに新生餒 化幼虫が現われる，そこで，サムプリングを行なつた時， 点がどの時期になるかによつて，幼虫数は多くなつた り，少なくなつたりする。そして，穂ばらみ期の長期灌 水 (13 日間) 除き，他の灌水期においては，常に餒化 直後の幼虫が $80 \%$ 以上を占めた. そして, サナギは全. くみられなかつた：この間の消息を図 7 に示す.このこ とは，幼虫は多数発生するが，サナギ，あるいは成虫に。

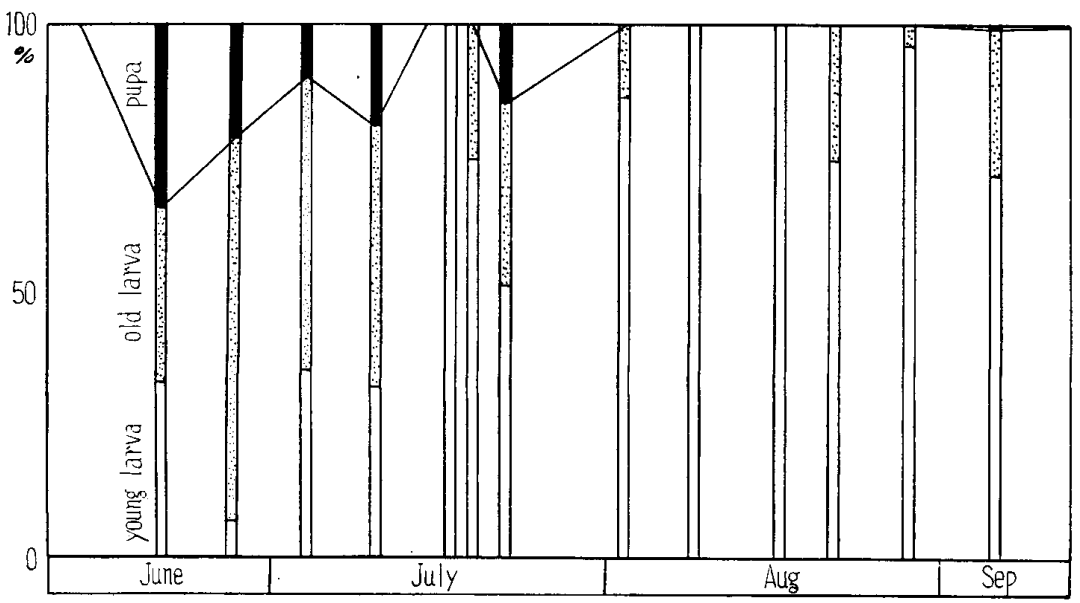

図 7 Culex tritaeniorhynchus の stage 構成の推移 1962年 
表 3 各水域における蚊の出現率の推移 1962年

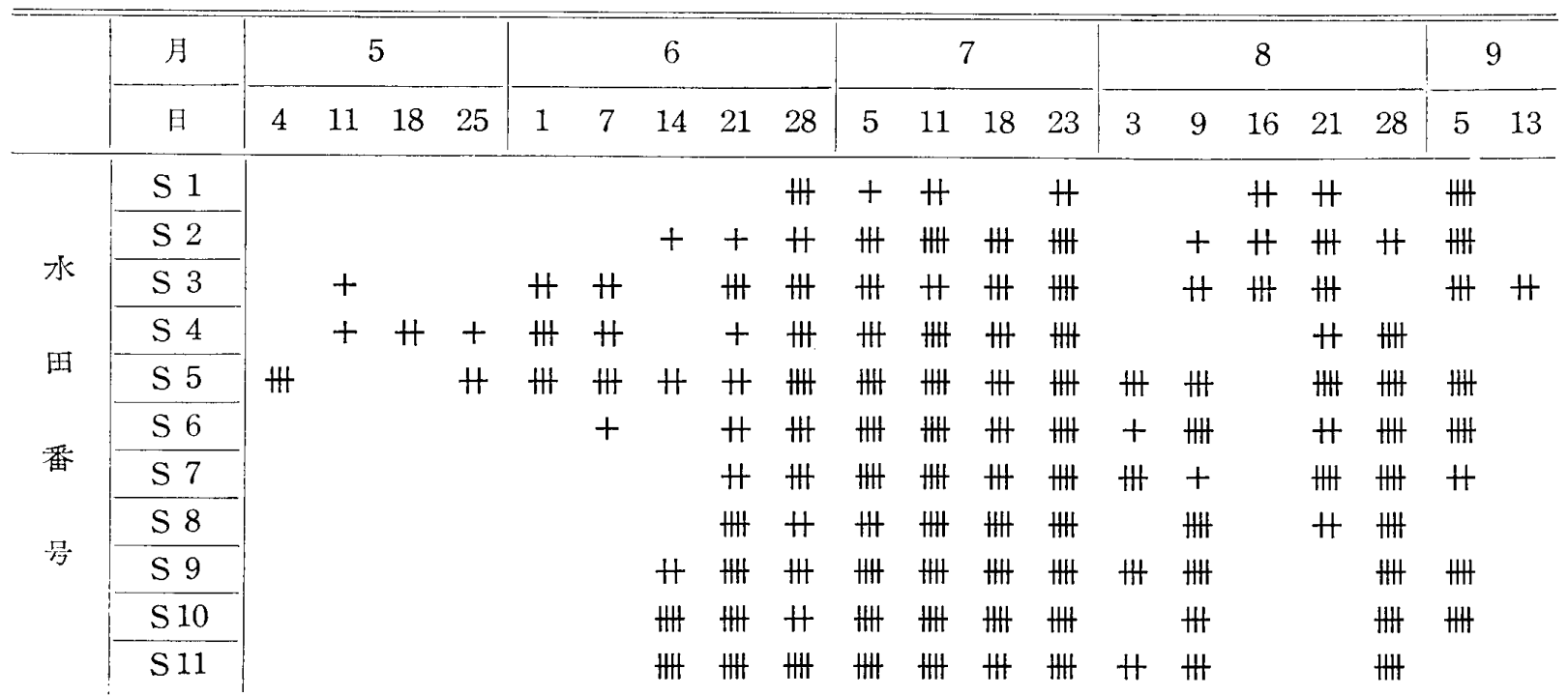

発生指数は次の階級で示した. 水域全域から1〜9 匹発生していると推定された時(十), $10 \sim 99$ 匹 $(H) ， 100 \sim 999$ 匹(卅)，1,000 匹以上 (冊).

達するに到らないで干田化のため死滅すると考えてよ い. 1 回の 13 日間を除いて，他の 7 回はわずか $1 \sim 4$ 日間の灌水期間しかないので，足あとなどの一部分の水 たまりに残るもの以外は，サナギにも達しないで死滅す ると考えてよい，9月 13 日の落水によつて, 全く干田 化し，水田からの幼虫の発生は終った.

第 4 期の特長は, 度重なる中干しのため, ほとんど成 虫に到らず幼虫は死滅することである，ただ，穂ばらみ 期の 13 日間の湛水時に, 老龄幼虫, サナギが増し, 成 虫を生じていたようである.

（5）全期を通覧してみると，この水田で，大量の蚊成 虫を生産している期間は, 第 2 期と第 3 期，つまり，田 植㨁後から，第 1 回中干しまでの 約 40 日間といえる. このことは図 $6 ， 7$, 表 3 によく表現されている.この 期間を徹底的に抑えることができればよい，

稻作作業の中で，最も大きく蚊の発生を支配している のは灌水条件である、水がなければ幼虫が育たないのは もちろんで，中干し，落水によつて，幼虫は全く死滅す る。発生期間が 40 日間というように短期間にしぼられ るのも，この水田における中干作業の励行によるもので 西る。隣接した蓮田における観察では，10月下旬まで sin, trit の幼虫がみられ，9月中的までは，はなはだ発 生量が多かつた：このことから考えると，中干し，落水 の効果注はなはだ大きいということがいえる。

水の他に，大きな抑圧要因になつたものに，パラチオ ン散布があつた．散布後約 10 日で，発生密度はほぼ元 通りに回復したが，散布直後は全滅した. 干田化，パラ チオン散布以外には，生息密度を強く抑える傾向をもつ た作業は見受けられなかつた。
著者らは，水田における蚊の発生実態を明らかにし， その上に立つて，防除法を追求寸る試みをもつている. その方法として大きく2つのことが考えられる．1つは 現行の稲作作業を, 蚊の発生を抑える方向変えていく といらこと. 1 つは, 全く別個の作業として殺虫剤の散 布を行ならといらことである. 後者については，すでに 実験を続行中で別報で報告の予定である。ここでは，前 者の方法について論義を行つてみたい.

もし, この水田で稲作作業法を変えて, 蚊の発生を抑 えようと考えれば，中干しが最も容易で効果的である. 仮にこの年の作業歴を基にして考えれば，活着分けつ期 に 2 回の中干しを追加し, 第 1 回の中干しを 4 日早めれ ばよいように思われる。 すなわち, 田植後 9 日間灌水し て，2 日間まず中干しする．ここで，その年の急激な増 加の出鼻を吒く. 9 日間の灌水は, 田植後 1 週間は, 稲 にとつて水が必要なためである，再び湛水すると，また 回復が起るので，7 日後再び中干しする.中田 (1962) は trit の幼虫期間は，14 日（6月），10日（7月）と報告し ているが，著者のパラチオン散布時の観察で法，6 日目 に老齢幼虫，9日目にサナギを見ているので，湛水期間 を 7 日以上のばすこと注危険と考えた. その後の湛水で 再び幼虫が発生するが， 7 月 14 日の農真散布で再び全 滅する。この効果もそら長くなく，9日目にはサナギが 出現するので，7日後には中干しの必要がある。この日 時は 7 月 21 日になり，この年の中干しの開始日より 3 日早いだけである. 実質的には, 田植と農薬散布の間に 2 回の中干しを行なえばよい，種々の農業専門書や川崎 市農業改良普及所の資料によつても，一般に，稲が水を 要求するのは，田植後約 1 週間，つまり活着期と， 8 月 
中旬の穂ばらみ期約 10 日間で，その他の時期は，必ず しも水を必要としない，伸長期には，地面が干割れしな い程度の干田では不都合でないとのことなので，稲作へ の影響なく，そして簡単な作業で大きな効果を上げ得る と考えられる.

一番問題になるのは，当該水田における作業歴や農法 が，他に対してどれほどの普遍性をもつかということだ が，少くとも当地方では，ほぼ標準に近いということだ つた. しかし, 中田 (1962) の京都付近の成績, 大利ら （1963）の長崎付近の成績と比較すると，作業歷にはか なり大きな違いが見られ，恐らく地域による差は大きい ものであろらことが想像される.

\section{5. 蚊成虫の季節的出現消長と気象環境}

前にも少し触れたように，同一場所で幼虫の発生消長 と, 成虫のそれとを観察したが，両者の間にはかなり大 きな相違があつた. もつとも，ライトトラップの有効捕 集範囲は，当該水田のみならず，広く他の地域も入るの で，全くの一致は期待できない。しかし，一帯は水田地 帯であり，むつと類似したパターンを示してもよいはず である。

図 8 に示されるように, 幼虫には 4 つのピークがみら れたが，成虫では 1 つの゚ークしかみられなかつた. し かも, 幼虫の 7 月上旬のピークからかなりおくれて 7 月 下旬に成虫のピークがある. そして, 成虫のピークはか なり急峻であり，8月以降になつて幼虫の発生がみられ

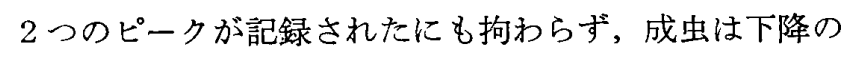
一途をたどる。

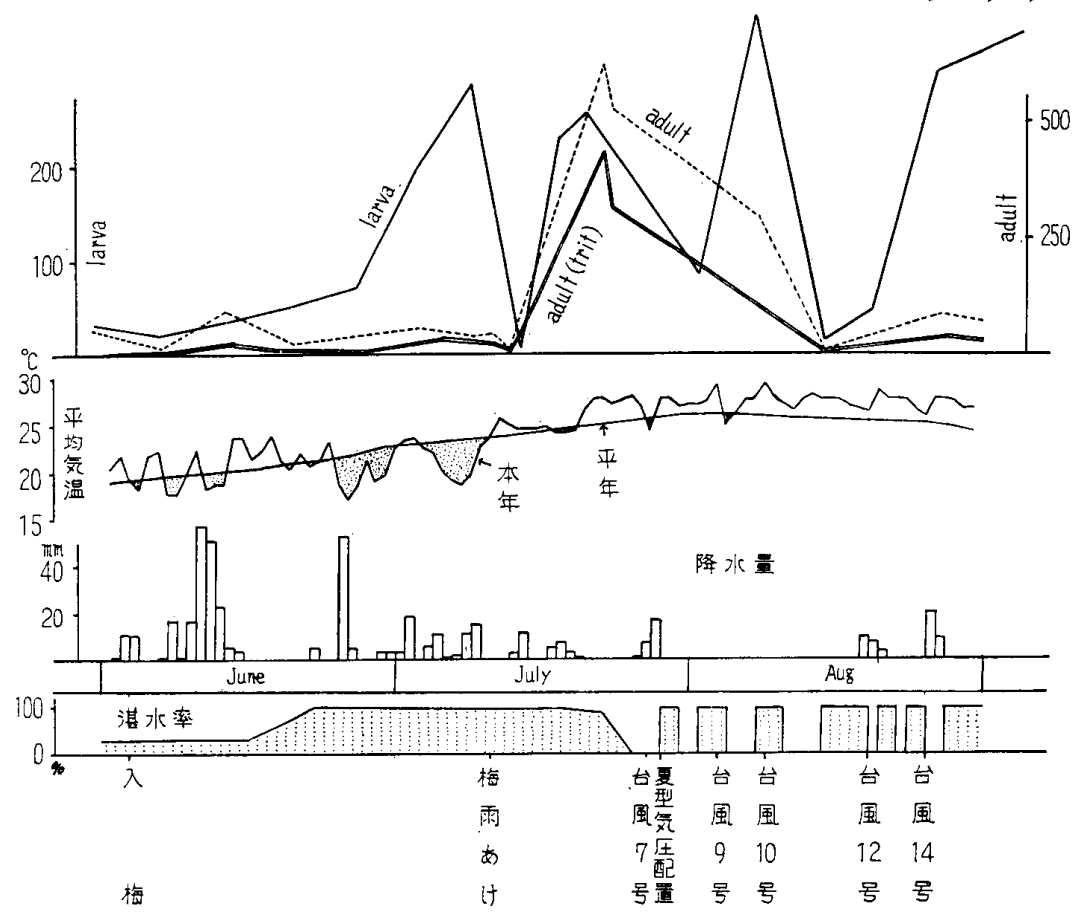

図8 蚊成虫の出現消長と気象環境 1962年
この間の関係をめぐつて, 次のような推察を下した。 すなわち，7月上旬の急激な幼虫の発生に伴なつて，成 虫の供給はかなり行なわれていると思われる.この成虫 がライトトラップに入らなかつたのは，気象環境条件の 規制によるものと考えた.この年は例年にない長梅雨で 図示されたよらに，6月3日の入梅以降，7月12日の 梅雨あけにいたる 40 日間，長雨が続いた，降水量の記 録に示されるように，この間雨は間断なく続いた。しか も，気温も例年に比心て低く，特に，6月 25 日から 7 月 10 日にいたる 16 日間は，大きく平均気温を下廻つた. この低温と降雨の 2 条件が, 成虫の活動を阻害し, ライ トトラップの捕集量を低めたのではないかと考えた。平 均気温は $17.5^{\circ} \mathrm{C}$ と $23.9^{\circ} \mathrm{C}$ の間を上下したが，成虫の 飛翔活動時刻の気温はこれをさらに下迴る筈である。

梅雨あけと同時に, 成虫の捕集量は急激に増加してき た. そして，平均気温が急激に上がつた 7 月 22 日 $(28.0$ $\left.{ }^{\circ} \mathrm{C}\right)$ の 1 日後に成虫のピークがみられた. この後, 成虫 捕集数の減少がみられるが，ちようどこの頃（7月 25 日）から中干しが始まつて，成虫の供給も止まる訳だか ら説明はつく．この後，幼虫のピークが 2 回あるが，い ずれも若龄幼虫に占められたピークで，サナギまで達す るものは少ないので，成虫の増大として現われてこない のは当然である.

7 月下旬における $t r i, \sin$ を中心にした蚊成虫の急峻 なピークは，すでに三田村ら(1940)によつて指摘された 「山田の頂き」に該当するものである．この「山田の頂 き」については，中田ら(1955)がすでに批判しているよ うに，すへての種類がこの時期に多いのではない。この 場合でも, trit と $\sin の 2$ 種によつて構成 されたピークである. ライトトラップによ る捕集量の変動は，野外集団の個体群の大 きさがそのまま反映されるのではなく，值 接的には，趆光性を通じて起る活動量が現 われてくるものである。この観点から考え ると, 発生源である水田の条件と, 成虫の 飛翔活動を規制する温度, 降雨などの気象 環境条件の二要因が，ライトトラップに示 される消長曲線に大きな役割を果たしてい るものと考えてよいだろう。

\section{まとめ}

1962 年 3 月から 11 月にいたる間, 川崎 市北郊の約 $42 \mathrm{a}$ の水田で, 防除を目的とし た蚊の発生動態の調查を行なつた、調查中 に得た種類は，4属 9 種で, コガタアカイ 
エカ, シナハマダラカが圧倒的に多く, 前 2 種より著る しく少ないが，キンイロヤブカ，コガタクロウスカがこ れについで多かつた。

水田では，コガタアカイエカとシナ八マダラカが圧倒 的であつたが，用水路では，コガタクロウスカが優占種 であつた。

水田における蚊幼虫発生の周年消長を論ずる場合，稲 作作業歴から，次の 4 期に区分して考えると都合がよか つた。第1期（苗代作りから田植まで：4月13日〜 6 月 11 日). 第 2 期（田植からパラチオン散布まで： 6 月 12 日～7月 14 日). 第 3 期（パラチオン散布から中干し 開始まで： 7 月 15 日 24日）。第 4 期（中干し開始から 落水まで： 7 月 25 日〜 9月 13 日). 第1 期は，まだ湛 水面積が狭く，季節も早く，幼虫の発生は少ない，土塊 の間の水たまりにキンイロヤブカが多かつた，第 2 期の 後半にコガタアカイエカ, シナハマダラカの急激な増加 がみられた． 6 月 21 日以降，全水田に幼虫の発生がみ られるようになつた。第 3 期は，パラチオン散布で始ま る．これで全滅した幼虫も，9日目にはほぼ元通り回復 する，そして，再び急激に増加するが，中干し開始によ つてここに第 2 のピークを作る. 第 4 期には，1〜5日 間の中干しが合計 8 回行なわれた。中干の間に灌水が行 なわれた時, 多数の幼虫が発生したが，羽化にはいたら ず次の中干しによつて死滅したようである。そして，9 月13日の落水で幼虫の発生注終りをつげた.

寸なわち，水田に扮ける蚊の発生は水によつて大きく 規制され，7月下旬から始まる徏繁な中干しによつて， 成虫の発生を許す期間は 6 月中句から 7 月下旬にいたる 約 40 日間であつた。この間, 7 月中旬に農薬散布が行 なわれるので，6月中旬から 7 月中旬にいたる間に対策 を講ずればよいと考えた１つの試案として，この年の 作業歴を基にすれば， 6 月 27 日頃と， 7 月 6 日頃の 2 回，中干しか，殺虫剤散布を行なえば，充分な駆除効果 を上げ得ることを確かめた。

ライトトラップによる成虫の出現消長と，水田の約虫 の消長との間には，そのパターンにかなりの相違がみら れた，その因果関係を論じ，この年の長梅雨と低温が成 虫捕集の時期をおくらせたこと。7月下旬以降は中干し によつて成虫になり得ず，このために成虫の補給が絶た

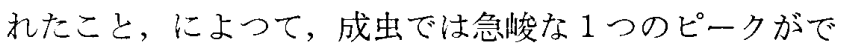
きたもの上考えた。

\section{参考文献}

1）加藤陸奥雄 (1955)：蚊の生態，144 pp. 東京. -

2) 三明村篤志郎・他 (1940)：岡山市に招ける昭和 14 年の蚊の消長とその日本流行性脳焱病毒保有につい
て。 日本医学及び 健康保険, 3208：743-745，-3) 永井威三郎 (1949)：実験作物栽培各論, 禾穀類篇, 540 pp. 養賢堂. 東京. 一-4) 中田五一, 伊藤寿美代 (1955): 京都市附近に㧍汀る蚊の生態学的研究 (2), light trap に捕集される蚊成虫相の周年遷移について. 衛生動物，6 (2)：82-93，一5) 中田五一 (1956)：生 態学的にみた日本の蚊. $24 \mathrm{pp}$. 日環協. 東京. 一6) 中田五一 (1962)：日本産蚊重科の分類学的並びに生 態学的研究. 衛生害虫, 6 (5-12) : 45-173。-7) 野 村健一 (1943)：本邦内地に於けるシナ八マダラカの 発生地㳊関寸る調查 (1)。資源研㽞報，(3)：3-61. -8）大利茂久他 (1963)：長崎地方の水田に抢ける蚊 幼虫の発生状況について。長崎大風土病紀要，5(1)： 53-59. - -9）神奈川県気象月報, 138-149 号.

\section{Summary}

In order to obtain basic data for paddy-field mosquito control, a survey of the mosquito population and its fluctuation was carried out during the season of 1962, at a paddy-field in the suburbs of Kawasaki.

The mosquitoes collected through the survey consist of nine species belonging four genera. Culex tritaeniorhynchus and Anopheles sinensis occupied the majority of the specimens collected from the paddy-field, whereas, Culex hayashii was a dominant species in the irrigation ditch.

During the period of the rice nursery, the breeding of mosquito larvae was not abundant yet, because of the area covered by water is restricted and the season is too early. After the riceplanttransplantation (June 11-17th), C. tritaeniorhynchus and $A$. sinensis increased remarkably. They were, however, entirely eradicated on July 14 th by the parathion spray which was made for the rice stem borer control. The population density of mosquitoes almost recovered nine days thereafter, and, on July 24 th, the second peak of mosquito abandance was observed when the drainage began. Drainage was repeated for eight times until the final one. (Sept. $13 \mathrm{th}$ ) when the irrigation ceased completely.

The period when the mosquito larvae most prevailed was estimated approximately 40 days begining from the riceplant-transplantation to the first drainage. It was fortunate to say that the parathion was applied in the middle of period giving favorable effect upon mosquito control. From the result stated above, the authors assume that if appropriate insecticide was applied twice between the riceplant-transplantation and the final drainage, or, drainage procedure was attempted twice, it will give a decisive effect upon the mosquito control in the paddy-field. 